\title{
Ethnobotanical study of medicinal plants in Ganta Afeshum District, Eastern Zone of Tigray, Northern Ethiopia
}

\author{
Leul Kidane ${ }^{1 *}$, Gebrecherkos Gebremedhin ${ }^{2}$ and Tadesse Beyene ${ }^{1}$
}

\begin{abstract}
Background: Starting from the ancient time, the people of Ethiopia use medicinal plants as traditional medicine to heal different human and livestock ailments. This ethnobotanical study of medicinal plants was carried out in Ganta Afeshum District, Eastern Zone of Tigray, Northern Ethiopia, to identify medicinal plant species used by the local community to treat various human and livestock ailments.

Methods: A total of 78 informants (54 men and 24 women) were selected to collect ethnobotanical information from four study sites. Among the 78 informants, 20 key informants were selected purposefully; the other 58 informants were selected randomly by lottery method. Ethnobotanical data were collected using semi-structured interviews, field observations, guided field walks, and group discussions and were analyzed by preference ranking, paired comparison, direct matrix ranking, informant consensus factor, fidelity level (FL), use-value, independent samples $t$ test, and Pearson correlation coefficients.
\end{abstract}

Results: A total of 173 medicinal plants were collected and identified that were distributed across 77 families and 156 genera. The family Fabaceae stood first by contributing 17 (9.8\%) species followed by Lamiaceae and Solanaceae with 9 (5.2\%) species each. Rhamnus prinoides was reported for the treatment of many of the described diseases. One hundred sixteen (67.1\%) medicinal plant species were collected from natural vegetation, 34 (19.7) were from home gardens, 13 (7.5\%) from farmland, and 10 (5.8\%) were from natural vegetation and home gardens. The most widely used life form was herbs (69 species, 39.9\%) followed by shrubs (58 species, 33.5\%). The most commonly used part of the medicinal plants was the leaves followed by roots. The plants were prepared by grinding, powdering, squeezing, roasting, and burning and were administered through oral, dermal, nasal, anal, ocular, and vaginal, and on the surface of the teeth. The most commonly used applications were by drinking, smearing, eating, fumigation, and chewing. There was no difference between men and women informants, showing that the two sexes had similar knowledge in the use of traditional medicinal plants. Educational level and medicinal plant knowledge of informants were negatively correlated; whereas age and medicinal plant knowledge of informants were positively correlated.

Conclusions: Ganta Afeshum District is relatively rich in diversity of medicinal plant resources accompanied with a rich indigenous knowledge within the local communities to harvest and effectively use to prevent different human and livestock ailments. However, nowadays, deforestation, agricultural expansion, overgrazing, drought, and overexploitation are threatening these properties. Therefore, people of the study area should apply complementary conservation approaches (in situ and ex situ) for sustainable use of these resources and to prevent species extinction.

Keywords: Diversity, Ethnomedicine, Extinction, Ganta Afeshum, Medicinal plant, Sustainable use, Tigray

\footnotetext{
* Correspondence: leulkw@gmail.com

'Department of Biology, College of Natural and Computational Sciences,

Mekelle University, P.O.Box 231, Mekelle, Ethiopia

Full list of author information is available at the end of the article
}

(c) The Author(s). 2018 Open Access This article is distributed under the terms of the Creative Commons Attribution 4.0 International License (http://creativecommons.org/licenses/by/4.0/), which permits unrestricted use, distribution, and reproduction in any medium, provided you give appropriate credit to the original author(s) and the source, provide a link to the Creative Commons license, and indicate if changes were made. The Creative Commons Public Domain Dedication waiver (http://creativecommons.org/publicdomain/zero/1.0/) applies to the data made available in this article, unless otherwise stated. 


\section{Background}

Humans began to employ plants for the intention of health a long time ago, maybe at the first moment when they suffered from diseases [1]. Since the antique time plants have been an essential supply for deterrent and healing for humans and livestock [2]. The population living in Sub-Saharan Africa continues to suffer from infectious as well as noninfectious and deficiency diseases [3]. Because of these and other problems, a large number of people of Africa die daily of preventable and curable diseases due to the lack of simple primary health care [4].

The ailment saddle is provoked by the limitation of the medical personnel and medical provisions such as remedial devices and access to fundamental medicine. The ratio of medical doctors to patients in Africa is not fair; in Ethiopia, for example, there is one doctor to 33,000 patients and in Malawi one doctor to 50,000 patients [5]. Because of this, human beings use different plant species known in ancient traditional medicine instead. Traditional medicine has been applied by humans for the healing of different diseases since a long time before the beginning of conventional medicine and up to this time serve the health care needs of the majority of the people of Africa [3, 5-7].

Thus, traditional medicine remains popular for both historical and cultural reasons. It is estimated that $80 \%$ of the African people depend on traditional medicine to meet up their care needs [8].

Like other parts of sub-Saharan countries, $70 \%$ of human and $90 \%$ of livestock population of Ethiopia rely on traditional medicine for primary health care [9]. In addition to the lack of availability of modern medicine, there are also culturally linked traditions. The communities have trust in the medicinal values of traditional medicine which can also be obtained at a relatively low cost as compared to the modern ones [10].

Ethiopia is exceptionally rich in history, culture, and biological diversity. It is the origin of the early of hominine species of which Lucy was a member. Around 80 languages are spoken by various ethnic groups. The country is also recognized for its diverse habitats, vegetation, and faith which results in a high diversity of traditional medicinal knowledge and practices of the people in using medicinal plants [11]. However, this rich cultural heritage is threatened, especially in the form of deforestation, fuelwood collection, illegal logging, overgrazing by stock animals, and agricultural expansion [11-13]. Such problems include the Tigray Region where the study was conducted.

Although the literature on ethnobotany in Ethiopia is increasing, there is still a limited ethnobotanical documentation on medicinal plants and minimum phytomedicine preparation of crude extracts and isolation of active ingredients [14]. Besides, the rural population of
Tigray in general and the people of Ganta Afeshum District in particular greatly depend on medicinal plants because of their acceptability, availability, affordability, and efficacy to treat human and livestock health problem and due to lack of certain infrastructure like roads, ambulance, hospital, and health center. However, these important medicinal plants become exhausted mainly due to agricultural and urban expansion as well as deforestation and heavy livestock grazing pressure.

Available reports show that limited ethnobotanical studies have been conducted in Tigray to document the use of medicinal plants [14-20]. The studies conducted in the districts of Alamata [14], Enderta [15], Hawzen [16], LaelayAdi-yabo [17], Asgede Tsimbela [18], Ofla [19], and Kilte Awulaelo [20] documented 25, 27, 33, 37, 68,113 , and 114 medicinal plants, respectively. However, no such study has so far been conducted in Ganta Afeshum District. Therefore, the protection of these resources and documentation of related traditional knowledge are needed, and it is on the basis of this gap that the present study was undertaken. The study examined and documented the diverse medicinal plant species which are used by the people of Ganta Afeshum District, Eastern Tigray Regional State Northern Ethiopia to treat different human and livestock ailments.

\section{Materials and methods}

Description of the study area and selection of study sites Tigray is located in Northern Ethiopia at $12^{\circ}$ and $15^{\circ}$ latitude and $36^{\circ}$ and $40^{\circ} \mathrm{N}$ east longitudes. The total area of Tigray is about $53,000 \mathrm{~km}^{2}$ with an average population density of $65 / \mathrm{km}^{2}$, and the population growth rate is $3 \%$. Most part of Tigray is arid or semi-arid with annual rainfall of 450 to $980 \mathrm{~mm}$. The total population is about 5.5 million, out of which $85 \%$ inhabit rural areas, deriving a livelihood from mixed crop/livestock subsistence agriculture [21]. The study area Ganta Afeshum District lies between $14^{\circ} 20^{\prime} \mathrm{N}$ and $32^{\circ} 29^{\prime} \mathrm{E}$ with a total area of $1636.36 \mathrm{~km}^{2}$. It is located $921 \mathrm{~km}$ north of Addis Ababa and $120 \mathrm{~km}$ north of Mekelle, the capital city of the regional state (Fig. 1).

There are 22,581 households with an average of 4.59 persons for a household in Ganta Afeshum District with a population density of 54.17 persons $/ \mathrm{km}^{2}$ [21] showing it is one of the most densely populated districts in Tigray Region. The main economy of the population in the wereda has full agriculture based on a mixed farming system. There are only 5 clinics with 114 health servants which provide modern health services. But, these health service buildings and the health servants cannot satisfy the needs of the huge population.

Based on the information gathered by a reconnaissance survey, four kebeles (study sites) at different distance from the administrative center of Adigrat were purposefully 

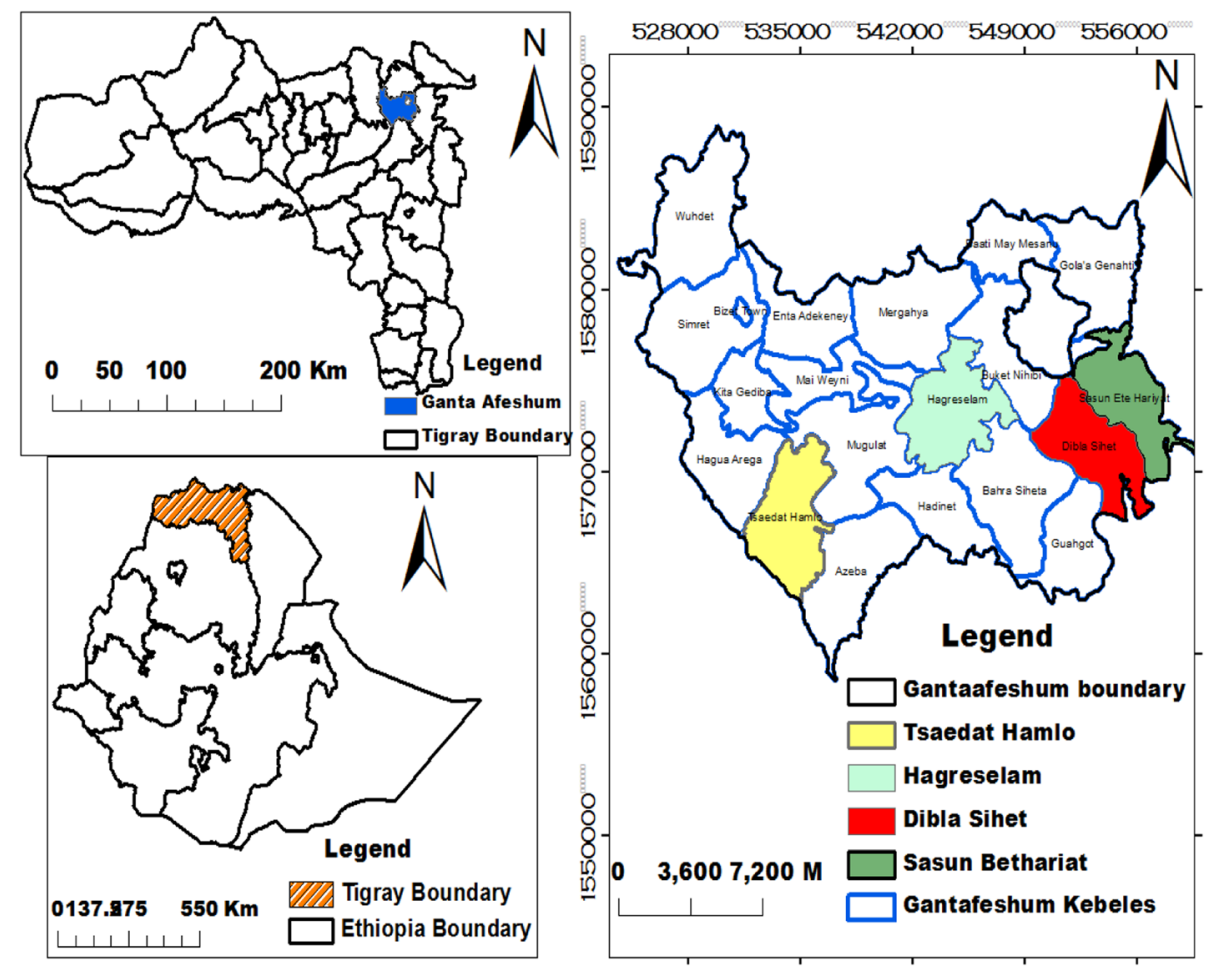

Fig. 1 Map of the study area

selected for the collection of ethnobotanical data. The four selected study sites were Sasun-Bethaweriat, Hagereselam, Dbla-Siet, and Tsaedat-Hamlo. The criteria for the selection of these study sites were availability of traditional practitioner healers and vegetation cover.

\section{Selection of informants}

A total of 78 individuals (54 men and 24 women) were selected randomly and purposefully with different ages (see Additional file 1: Table S1). Out of the 78 individuals, 58 were selected randomly by a lottery method from the total households in order to give equal chances, and 20 key informants who are traditional healers and knowledgeable persons were selected purposefully based on the recommendations of local authorities, elders, and religious leaders. The key informants in the study area are very few and they were purposely selected because of their knowledge and relevance (Table 1).

\section{Determining sample size}

In order to collect ethnobotanical data, men and women household informants with different age were selected from four kebeles, and the sample size was determined using Cochran's sample size formula as indicated by Bartlett et al. [22] as follows:

$$
n=\frac{N}{1=N(e)^{2}}
$$

where $n$ is the sample size of the research, $N$ is the total number of households in the district (22581), $e$ is the maximum variability of making error $5 \%(0.05)$, and 1 is the probability of event occurring.

$$
n=22581 / 1+22581(0.05)^{2}
$$

$n=393$ which is based on the total number of households of the district (from the 20 kebeles of the district);

\begin{tabular}{|c|c|c|c|c|c|c|c|c|c|}
\hline \multirow{2}{*}{$\begin{array}{l}\text { District } \\
\text { Ganta Afeshum }\end{array}$} & \multirow[t]{2}{*}{ Kebele } & \multirow[t]{2}{*}{ Total households } & \multicolumn{3}{|c|}{ General informants } & \multicolumn{3}{|c|}{ Key informants } & \multirow[t]{2}{*}{ Total } \\
\hline & & & M & $\mathrm{F}$ & Total & M & $\mathrm{F}$ & Total & \\
\hline & Tsaedat-Hamlo & 1082 & 7 & 5 & 12 & 5 & 1 & 6 & 18 \\
\hline & Hagerselam & 1308 & 13 & 4 & 17 & 3 & 2 & 5 & 22 \\
\hline & Sasun-Bethaweriat & 1094 & 10 & 4 & 14 & 3 & 2 & 5 & 19 \\
\hline & Dbla-Siet & 1114 & 11 & 4 & 15 & 2 & 2 & 4 & 19 \\
\hline Total & & 4598 & 41 & 17 & 58 & 13 & 7 & 20 & 78 \\
\hline
\end{tabular}

Table 1 Number of general and key informants 
but our study sites were four kebeles. Therefore, the sample size for each of these "four kebeles" was calculated using the proportion of the number of households in each kebele to the total number of the household in the district.

\section{Collection of ethnobotanical data}

Ethnobotanical data were collected during January and February 2017 through semi-structured interviews, field observation, guided field walk, and focus group discussion. The semi-structured interviews were based on the questions prepared beforehand in English language that were translated into Tigrigna that is the mother language of the informants.

\section{Semi-structured interviews}

The semi-structured interviews followed Martin [23] in order to obtain ethnobotanical information such as medicinal plant species, common human and livestock ailments, methods of preparation, dosage, routes of administration, vernacular names of the medicinal plants, plant parts used, and conservation and threats of the medicinal plants.

\section{Field observation}

During the field observations, information about land form, soil type, distribution of medicinal plants, conservation activities and threats of medicinal plants, habit, and habitat of medicinal plants was recorded on site.

\section{Guided field walks}

Guided field walks were carried out with the assistance of local guides and interviewees on the study sites combined with interviews in order to obtain essential ethnobotanical information as well as to gather medicinal plant specimens by recording all the necessary information of the particular medicinal plant species, such as local name, parts used, and diseases treated by the medicinal plant.

\section{Group discussions}

Group discussions were made with seven to ten informants at each study site composed of knowledgeable traditional healers in order to collect information about the local soil and land classification, topographic classification, indigenous vegetation classification, and threats and conservation activities of medicinal plants.

\section{Medicinal plant specimen collection and identification}

During the field investigation, plants with medicinal value were collected from home gardens and from the wild and cultivated areas. Essential information such as local name and habit was recorded and herbarium specimens collected. For plant identification, the Flora of
Ethiopia and Eritrea [24-31] was used. The accuracy of the identifications was confirmed by the comparison with the deposited authenticated specimens from Addis Ababa University Herbarium and by the help of taxonomists.

\section{Data presentation and analysis}

The ethnobotanical data were analyzed both qualitatively and quantitatively using informant consensus factor (ICF), fidelity level index (FLI), preference ranking, paired comparisons, Jaccard's coefficient of similarity, and direct matrix ranking. Diseases recorded in this study were grouped into nine major categories associated with specific symptoms and signs with the help of a medical doctor, and informant consensus factor (ICF) was calculated to determine the effectiveness of medicinal plants in each ailment category according to Heinrich et al. [32]. The ICF computed every category to discover the accord of informants on the reported therapy for the group of diseases. It was calculated as follows: numbers of use citation in each category $\left(n_{u r}\right)$ minus the number of species used $\left(n_{t}\right)$, divided by the number of use citations in each category minus one. The result of the calculation (ICF) is from 0 to1. According to Heinrich et al. [32], the higher the value, the more consensuses of the informants.

$$
\begin{aligned}
& \mathrm{ICF}=n_{u r}-n_{t} \\
& n_{u r-1}
\end{aligned}
$$

where ICF is the informant consensus factor, $n_{u r}$ is the number of use citation in each category, and $n_{t}$ is the number of species used.

The FL index quantifies the importance of a species for a given purpose. Most commonly used medicinal plants have high fidelity level index, thus used and agreed by large number of people, whereas medicinal plants that are not commonly used have low fidelity level index and the informants vary on that species in the treatment of particular ailments [33]. Fidelity level index was used to determine the relative healing potential of medicinal plants against human or livestock ailments based on the proportion of informants' agreement on the use of a given medicinal plant. The formula for FL is given as [34]:

$$
\mathrm{FL} \%=\mathrm{Ip} / \mathrm{IU} \times 100
$$

where FL\% is the percentage of fidelity level, Ip is the number of informants who independently indicated the use of a species for the same major ailments, and IU is the total number of informants who mentioned the plant for any major ailment. 
Table 2 Diversity of medicinal plant species belonging to each plant family

\begin{tabular}{llll}
\hline No. & Family & Number of medicinal plant species & Percentage \\
\hline 1 & Fabaceae & 17 & 9.8 \\
2 & Lamiaceae & 9 & 5.2 \\
3 & Solanaceae & 9 & 5.2 \\
4 & Asteraceae & 8 & 4.6 \\
5 & Apiaceae & 6 & 3.5 \\
6 & Euphorbiaceae & 6 & 3.5 \\
7 & Asclepiadaceae & 5 & 2.9 \\
8 & Cucurbitaceae & 5 & 2.9 \\
9 & Amaranthaceae & 4 & 2.3 \\
10 & Moraceae & 4 & 2.3 \\
11 & Polygonaceae & 4 & 2.3 \\
12 & Rutaceae & 4 & 2.3 \\
& Others & 92 & 53.2 \\
& Total & 173 & 100 \\
\hline
\end{tabular}

The use value was also calculated to see the relative importance of selected traditional medicinal plant species for treating diseases in the study area according to Phillips et al. [35]. It was calculated by the formula $\mathrm{UV}=\Sigma U i / n$ where UV stands for the total use value of the traditional medicinal plant species, $U$ refers to the number of use reports cited by each informant for a given plant species, and $n$ stands for the total number of informants interviewed for a given plant species.

Preference ranking was conducted by asking informants to rank the most important medicinal plants that were frequently used by the local community based on their preference and the importance in the community. The most preferred medicinal plants scored 5 while the least preferred medicinal plant by the informants scored 1. These numbers were summed for all informants, giving an overall ranking for the medicinal plants by sample group of the informants [23].
Direct matrix ranking draws explicitly upon multipurpose dimensions. Direct matrix ranking was performed following the method of Martin [23] to medicinal plant species for their multipurpose use and to relate this to the extent of its utilization versus its dominance. The values of each use diversity for a species were taken, and the value of each species was summed and ranked.

A paired comparison was conducted following [23]. A list of the pairs of selected medicinal plants with all possible combinations was made, and a sequence of the pairs and the order within each pair were randomized before every pair was presented to selected informants; their response recorded and the total value summarized. Besides, independent sample $t$ test was calculated in order to compare the average traditional medicinal plant knowledge of men and women informants by using SPSS software.

Jaccard's coefficient of similarity (JCS) was performed to evaluate medicinal plant species composition and similarity among different areas. The similarity was calculated between the present study area (Ganta Afeshum District) and other areas of a similar agroecological zone which have been studied by other researchers in different parts of Ethiopia. The formula of JCS is represented as [36]:

$$
\mathrm{JCS}=\frac{c}{(a+b+c)}
$$

where JCS is Jaccard's coefficient of similarity, $a$ is the number of species which is found in habitat $\mathrm{A}, b$ is the number of species found only in habitat $\mathrm{B}$, and $c$ is the number of common species found in habitats $A$ and $B$.

\section{Results}

The informants involved in the present study were 17-79 years old with an average age of 47 years. From the total informants, $45(57.7 \%)$ were in the age range of $38-58$, while 17 of the informants were

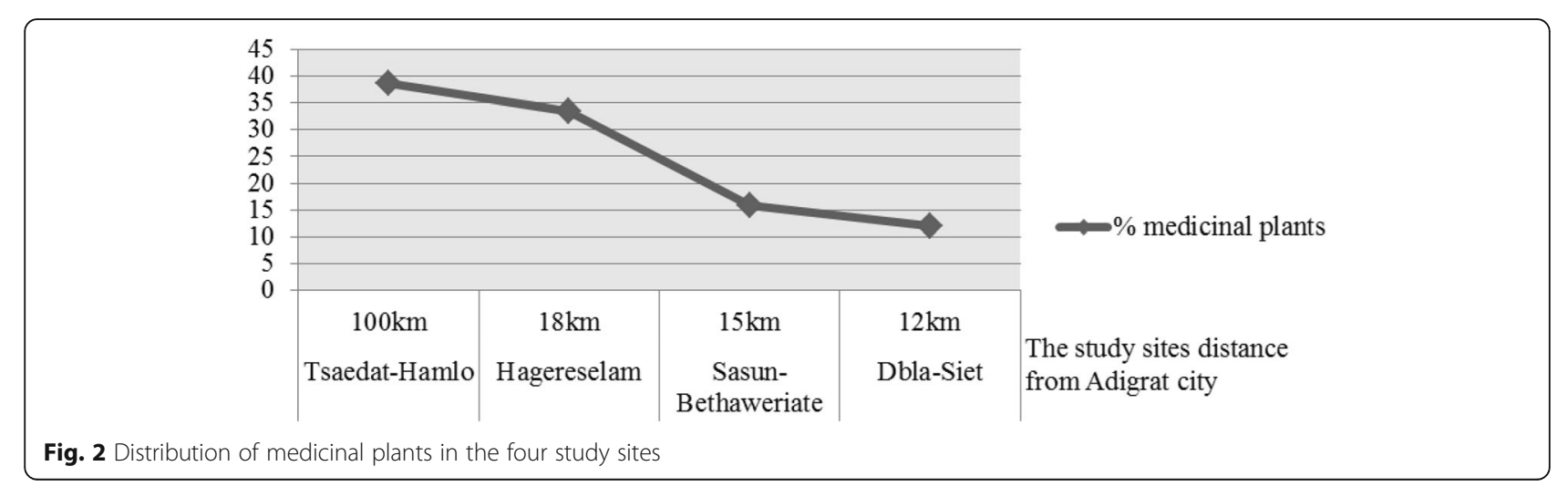


Number of medicinal plants

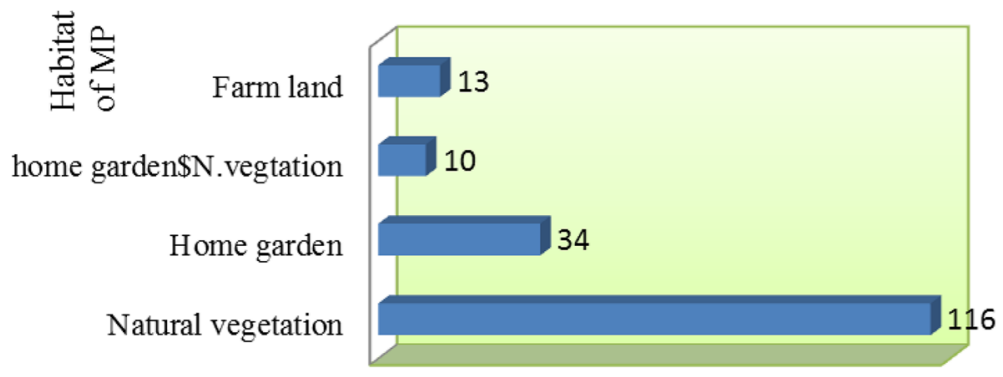

Fig. 3 Source of medicinal plants in the study area

59-79 years old and 16 were in the age range of 17-37 years old (see Additional file 1: Table S1).

More than half of the informants $(43,55.1 \%)$ were illiterate, and 21 (26.6\%) of the informants had been in school for 1-8 years, 12 (15\%) of the informants finished school in grade 9-12, and the remaining 2 had schooling above grade 12 . From the 54 men informants, 47 were married while 7 men informants were single. From the total of 24 women informants, 11 were married whereas 13 women informants were single.

\section{Medicinal plants in the study area Diversity of medicinal plants}

From the four study sites, a total of 173 medicinal plant species were documented (see Additional file 2: Table S2). These were distributed across 77 plant families and 156 genera. The family Fabaceae stood first by contributing 17 (9.8\%) species followed by Lamiaceae and Solanaceae with 9 (5.2\%) species each (Table 2).

\section{Distribution of medicinal plants in the study sites}

The medicinal plants were unevenly distributed in the four study sites: $38.6 \%$ in Tsaedat-Hamlo, $33.5 \%$ in
Hagereselam, 15.9\% in Sasun-Bethaweryat, and 12.1\% in Dbla-Siet (Fig. 2).

\section{Source of medicinal plants}

From the 173 medicinal plant species, 116 (67.4\%) were gathered from the natural vegetation followed by 34 (19.7\%) from home gardens (Fig. 3).

\section{Growth form (habit) of medicinal plants}

The collected medicinal plant species have diverse life forms. From a total of 173 medicinal plants, 69 (39.9\%) were herbs which constitute the highest number followed by shrubs 58 (33.5\%) (Fig. 4).

\section{Parts of the medicinal plants used}

Leaves were the most commonly used part of the medicinal plants and accounted for 129 species (38.6\%) followed by roots $57(17.4 \%)$ and seeds 38 (11.4\%) (Table 3).

\section{Conditions of preparation}

Plants were prepared fresh, dry, or both fresh and dry. The majority of $212(64 \%)$ were prepared in fresh form followed by dry 78 (23\%) (Fig. 5).

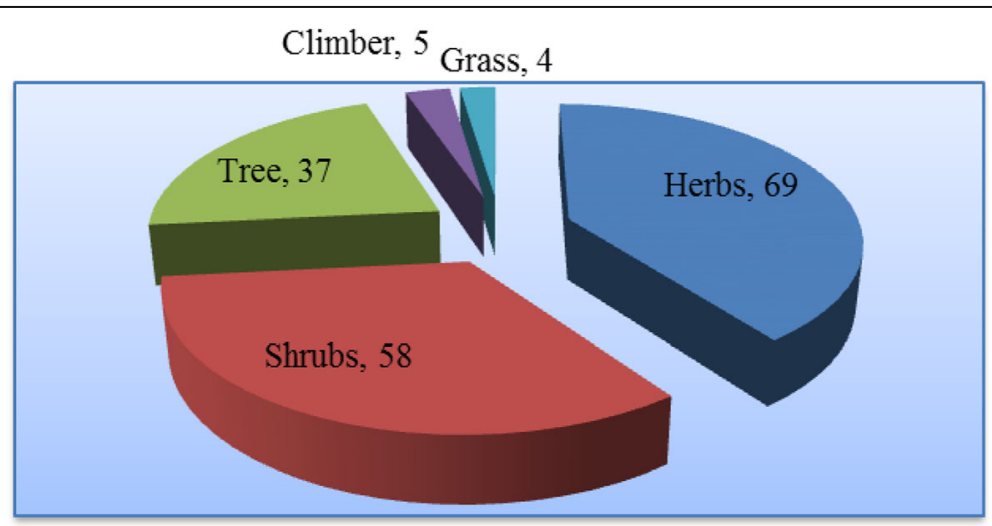

Fig. 4 Habit of medicinal plants 
Table 3 Medicinal plant parts used in traditional medicines

\begin{tabular}{lll}
\hline Part used & Number & Percentage \\
\hline Leaf & 129 & 38.62 \\
Root & 57 & 17.06 \\
Seed & 38 & 11.38 \\
Fruit & 32 & 9.58 \\
Bulb & 23 & 6.88 \\
Bark & 19 & 5.68 \\
Latex & 11 & 3.29 \\
Stem & 7 & 2.09 \\
Leaf and root & 6 & 1.79 \\
Whole plant & 5 & 1.49 \\
Flower & 3 & 0.89 \\
Leaf and stem & 2 & 0.59 \\
Root and bark & 2 & 0.59 \\
Total & 334 & 100 \\
\hline
\end{tabular}

\section{Method of preparation}

It is known that there are different ways to prepare medicinal plants to treat human and livestock ailments. In the case of Ganta Afeshum District, the major method of preparation was direct and immediate/unprocessed use of the medicinal plants which amounted to $17.9 \%$, followed by grinding $16.8 \%$ (Table 4 ).

\section{Routes of administration}

The result showed that the traditional medicine was administered through different routes; the most common one was orally that accounted for $144(43.1 \%)$ followed by dermal which account for 114 (34.1\%) (Fig. 6).

\section{Modes of application}

The data collected from the study area showed that many of the prepared remedies were taken by drinking that accounted for $24.3 \%$ followed by smearing $22.8 \%$ (Table 5).

\section{Solvents and ingredients used}

The preparation of traditional medicine needs solvents and ingredient. The major solvent was water that accounts for $34.4 \%$, but honey, butter, and cereal oils were also widely used ingredients (Table 6).

Ailments of humans that can be treated by medicinal plants In the study area, 74 human ailments were identified to be treated by many medicinal plants (see Additional file 3: Table S3). It was found that single medicinal plant species can treat a number of human ailments, and single ailments can be treated by many medicinal plant species. For example, wounds can be treated by 20 medicinal plants and febrile illness, abdominal pain, headache, and cough can be treated by 15 medicinal plant species each (Table 7).

\section{Ailments of livestock that can be treated by medicinal plants}

In the study area, 96 medicinal plants were identified for the treatment of 23 livestock ailments (see Additional file 4: Table S4). Like for humans, one livestock ailment can be treated by several medicinal plants; for instance, leech can be treated by 12 medicinal plants, diarrhea and shivering (locally called halfyen) can be treated by 13 medicinal plants each (Table 8).

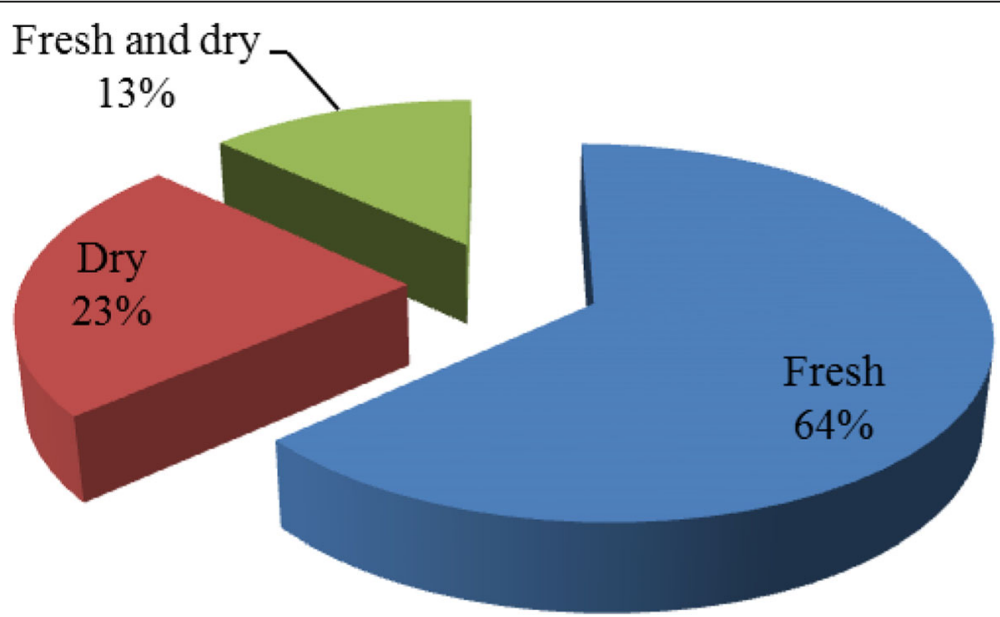

Fig. 5 Condition of remedy preparation of medicinal plants 
Table 4 Methods used in the preparation of remedies

\begin{tabular}{|c|c|c|c|}
\hline No. & Method of preparation & Frequency & Percentage \\
\hline 1 & Direct and immediate/unprocessed use of medicinal plants & 60 & 17.96 \\
\hline 2 & Grinding part of the medicinal plants & 56 & 16.75 \\
\hline 3 & Grinding then mixing with water, honey, and other & 52 & 15.57 \\
\hline 4 & Boiling in water, milk, honey, and other & 37 & 11.08 \\
\hline 5 & Grinding and then filtering & 28 & 8.38 \\
\hline 6 & Powdering and then mixing with water, honey, and other & 27 & 8.08 \\
\hline 7 & Burning & 17 & 5.09 \\
\hline 8 & Powdering & 16 & 4.79 \\
\hline 9 & Heating & 7 & 2.09 \\
\hline 10 & Squeezing & 6 & 1.79 \\
\hline 11 & Roasting & 4 & 1.2 \\
\hline 12 & Powdering and cooking & 3 & 0.9 \\
\hline 13 & Grinding and boiling & 4 & 1.2 \\
\hline 14 & Grinding and soaking & 2 & 0.6 \\
\hline 15 & Grinding and then burning & 2 & 0.6 \\
\hline 16 & Powdering and heating & 2 & 0.6 \\
\hline 17 & Grinding and squeezing & 2 & 0.6 \\
\hline 18 & Powdering and boiling & 2 & 0.6 \\
\hline 19 & Powdering and smoking by burning & 2 & 0.6 \\
\hline 20 & Powdering and heating then mixing & 2 & 0.6 \\
\hline 21 & Roasting and then grinding & 2 & 0.6 \\
\hline \multirow[t]{2}{*}{22} & Soaking & 1 & 0.3 \\
\hline & Total & 334 & 100 \\
\hline
\end{tabular}

\section{n Count}

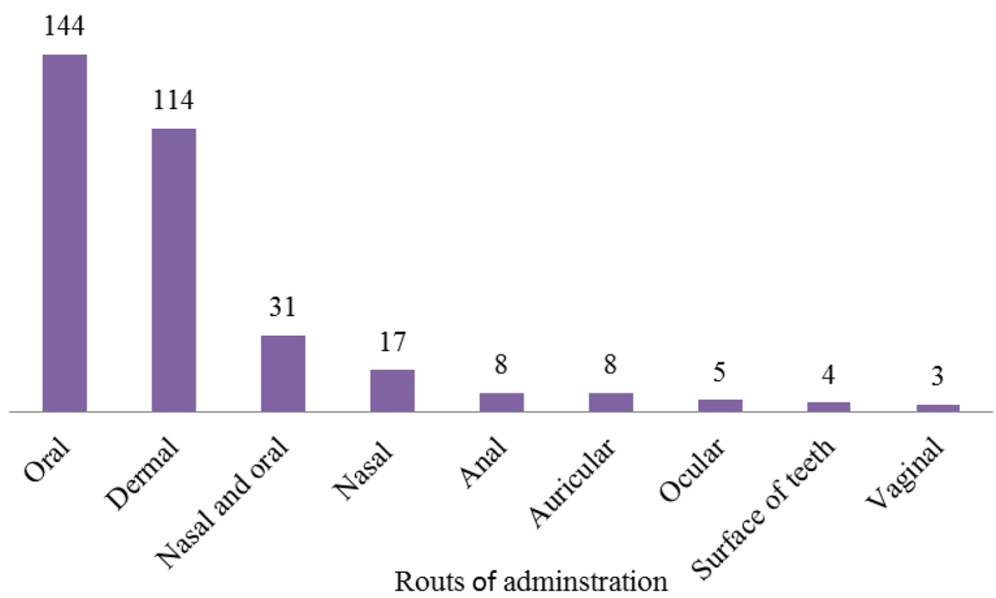

Fig. 6 Route of remedy administration for treatment of human and livestock ailments 
Table 5 Methods of application of medicinal plants

\begin{tabular}{llll}
\hline No. & Modes of application & Frequency & Percentage \\
\hline 1 & Drinking & 81 & 24.25 \\
2 & Smearing & 76 & 22.75 \\
3 & Eating & 35 & 10.48 \\
4 & Fumigation & 34 & 10.18 \\
5 & Chewing & 19 & 5.69 \\
6 & Tie & 17 & 5.09 \\
7 & Swallowing & 15 & 4.49 \\
8 & Sniffing & 13 & 3.89 \\
9 & Rubbing & 13 & 3.89 \\
10 & Dropping & 12 & 3.59 \\
11 & Washing & 8 & 2.39 \\
12 & Smelling & 3 & 0.89 \\
& Total & 334 & 100 \\
\hline
\end{tabular}

Medicinal plants used for treatment of both humans and animals

In Ganta Afeshum District, 15 types of human and livestock ailments were recorded and 22 medicinal plants were identified to treat both human and livestock ailments (Table 9) (see Additional file 5: Table S5).

\section{Informants' knowledge on traditional medicinal plants}

Comparison between sexes

The result for the comparison between men and women in traditional medicinal plant knowledge showed that the difference is not statistically different (Table 10).

Table 6 Solvents and ingredients used in the preparation of traditional medicines

\begin{tabular}{llll}
\hline No. & Solvents and ingredients & Frequency & Percentage \\
\hline 1 & Water & 43 & 34.4 \\
2 & Honey & 28 & 22.4 \\
3 & Butter & 19 & 15.2 \\
4 & Cereal oils & 7 & 5.6 \\
5 & Tella/teji/brzi & 6 & 4.8 \\
6 & Milk/ergo & 5 & 4 \\
7 & Tea/coffee & 4 & 3.2 \\
8 & Animal fat & 4 & 3.2 \\
9 & Animal urine & 1 & 0.8 \\
10 & Animal bile & 1 & 0.8 \\
11 & Others & 7 & 5.6 \\
& Total & 125 & 100 \\
\hline
\end{tabular}

Table 7 Human ailments that can be treated by medicinal plants

\begin{tabular}{lll}
\hline No. & Human ailments & $\begin{array}{l}\text { No. of medicinal plants } \\
\text { used to treat the ailment }\end{array}$ \\
\hline 1 & Wound & 20 \\
2 & Febrile illness & 15 \\
3 & Abdominal pain & 15 \\
4 & Headache & 15 \\
5 & Cough & 15 \\
6 & Evil eye & 12 \\
7 & Evil spirit & 11 \\
8 & Men impotence & 9 \\
9 & Tonsillitis & 8 \\
10 & Bone dislocated & 8 \\
11 & Hemorrhoids & 8 \\
12 & Ear infection & 8 \\
13 & Asthma & 8 \\
14 & Skin rash & 7 \\
15 & Toothache & 6 \\
16 & Tapeworm & 6 \\
17 & Constipation & 6 \\
18 & Cutaneous leishmaniasis & 6 \\
19 & Body swelling & 5 \\
20 & Paralysis & 5 \\
& Other & 118 \\
\hline & Total & 311 \\
\hline & & \\
\hline & & 6
\end{tabular}

Comparison between married and single informants

The result of independent sample $t$ test indicated that there is a significant knowledge difference between married and single informants (Table 11).

\section{Comparison between the key and general informants}

Analysis using the SPSS computer program showed that there was a significant mean knowledge difference between the key informants and general informants (Table 12).

\section{Differences in knowledge depending on educational background}

There was a significant negative correlation between the informants' educational level and the number of medicinal plants reported (Pearson correlation coefficient, $r=-0.959$, at $\alpha=0.05, p=0.041$ ).

\section{Differences in knowledge depending on age}

There was a positive correlation between the age and the knowledge of traditional medicinal plants of the informants, in the study area (Pearson correlation coefficient, $r=0.339, p=0.780$ ). 
Table $\mathbf{8}$ Livestock ailments that can be treated by medicinal plants

\begin{tabular}{|c|c|c|}
\hline No. & Livestock ailment & $\begin{array}{l}\text { No. of medicinal } \\
\text { plants used to treat } \\
\text { livestock ailment }\end{array}$ \\
\hline 1 & Leech & 12 \\
\hline 2 & Diarrhea and shivering & 13 \\
\hline 3 & Bloating & 11 \\
\hline 4 & Newcastle disease & 7 \\
\hline 5 & Abdominal pain & 7 \\
\hline 6 & Wound & 5 \\
\hline 7 & Body swelling & 5 \\
\hline 8 & Hornworm & 4 \\
\hline 9 & Evil spirit & 4 \\
\hline 10 & Bone fracture & 4 \\
\hline 11 & Fleas and lice & 3 \\
\hline 12 & Eye diseases & 3 \\
\hline 13 & Anthrax & 3 \\
\hline 14 & Ticks & 3 \\
\hline 15 & Skin rash & 2 \\
\hline 16 & Prolonged delivery & 2 \\
\hline 17 & Fascioliasis & 2 \\
\hline 18 & Blackleg & 1 \\
\hline 19 & Urine retention & 1 \\
\hline 20 & Rabies & 1 \\
\hline 21 & Malaria & 1 \\
\hline 22 & Cough & 1 \\
\hline \multirow[t]{2}{*}{23} & Evil eye & 1 \\
\hline & Total & 96 \\
\hline
\end{tabular}

\section{Informant consensus factor}

The informant consensus factor (ICF) was calculated. The highest values were obtained for febrile illness and tonsillitis (0.866) followed by abdominal pain, diarrhea, tapeworm, amoeba and gastritis (0.645), and wound, skin rash, cutaneous leishmaniasis, ringworm, irritation, and skin rash (0.458). Ear infection, eye problem, and the category of heart diseases, blood pressure, and Rh factor had lower ICF (Table 13).

\section{Fidelity level index}

Withania somnifera, Lagenaria siceraria, Nigella sativa, Laggera tomentosa, Silybum marianum, Plectranthus lanuginosus, Linum usitatissimum, Chenopodium ambrosioides, Vernonia amygdalina, and Asparagus africanus had the highest fidelity level values, and this was an indication of their good healing potential in the study area (Table 14).
Table 9 Human and livestock ailment that can be treated by medicinal plants

\begin{tabular}{lll}
\hline No. & Human and livestock ailment & $\begin{array}{l}\text { No. of medicinal } \\
\text { plants used to treat } \\
\text { human and livestock } \\
\text { ailment }\end{array}$ \\
\hline 1 & Abdominal pain & 4 \\
2 & Diarrhea & 2 \\
3 & Bone fracture & 2 \\
4 & Malaria & 2 \\
5 & Skin rash & 2 \\
6 & Wound & 1 \\
7 & Cough & 1 \\
8 & Evil spirit & 1 \\
9 & Evil eye & 1 \\
10 & Eye diseases & 1 \\
11 & Urine retention & 1 \\
12 & Body swelling & 1 \\
13 & Prolonged delivery & 1 \\
14 & Rabies & 1 \\
15 & Dislocated bone & 1 \\
& Total & 22 \\
\hline
\end{tabular}

\section{Preference ranking}

The five most mentioned medicinal plants (Table 15) were reported for the efficient treatment of febrile illness, and they were selected for preference ranking. Ten key informants were asked to rank the given medicinal plants based on their usefulness, 5 for the medicinal plant which they thought is the most successful for the treatment of febrile illness, and 1 for the least effective plant. Cordia africana was ranked first (Table 15).

\section{Use value and use diversity of medicinal plants in the study} area

Of the total 173 medicinal plants documented, 50 (28.90\%) had only medicinal importance. The other 123 (71.09\%) species had some additional purpose besides medicinal value (Table 16).

The calculated results of use values (UV) showed that Rhamnus prinoides scored the highest use values (4.5) followed by Cordia africana and Ruta chalepensis than other species (Table 17).

\section{Direct matrix ranking}

In addition to medicine, the local community used the plants for various purposes such as firewood, charcoal making, for eating as edible fruit, construction, and furniture. The result of direct matrix ranking showed that Carissa spinarum, Acacia etbaica, Juniperus procera, Cordia africana, Olea europaea, Mimusops kummel, Ziziphus spina-christi, and Acacia albida were ranked 
Table 10 Independent sample $t$ test to compare men and women knowledge of traditional medicinal plants

\begin{tabular}{llllllll}
\hline Social group & Informants type & $N$ & Average & SD & $t$ value & $d f$ & $p$ value \\
\hline Gender & Men & 54 & 11.70 & 7.830 & -0.795 & 76 & 0.429 \\
& Women & 24 & 13.21 & 7.431 & -0.812 & 46.4 & 0.421 \\
\hline
\end{tabular}

first to eighth, respectively. Likewise, the six use values report on eight selected plant species were summed up and ranked, and the result showed firewood, charcoal, medicinal, construction, furniture and farm tools, edible fruit were ranked first, second, third, fourth, fifth, and sixth, respectively (Table 18).

\section{Paired comparison}

The disease tonsillitis, locally known as hanate commonly attacks children, and it can be treated by using several medicinal plants. The result indicated that Rhamnus prinoides and Achyranthes aspera were the most preferred and effective treatment (Table 19).

\section{Comparison with other districts through Jaccard's coefficient of similarity}

The highest Jaccard's coefficient of similarity in the composition of medicinal plants was found between the study area and Kilte Awulaelo District, whereas similarity was less with Tahitay Adiyabo and Kafta Humera districts (Table 20).

The degree of similarity between the study area and other areas might relate to vegetation types as well as soil types and climatic conditions in the region.

\section{Source and transfer of traditional medicinal plant knowledge}

The highest traditional medicinal plant knowledge was acquired from family members that is $39.74 \%$ from the father and $24.35 \%$ from the mother, followed by religious institutions $(8.9 \%)$, reading books $(6.41 \%)$, and as a gift from God (5.12\%) (Fig. 7).

\section{Threats to medicinal plants and associated knowledge}

Agricultural expansion was mentioned as the main threat to medicinal plants in the study area followed by cutting trees for firewood and for charcoal making (Fig. 8).

According to the informants, the indigenous knowledge of medicinal plants was faced with many challenges, and the transmission of this knowledge and practice of traditional medicine was in danger due to the unwillingness of the young generation to gain the traditional medicinal plant knowledge. Also, the traditional healers do not show the medicinal plants freely to anybody (Table 21).

\section{Discussion}

One hundred seventy-three medicinal plant species were identified for the treatment of human and livestock ailments that distributed across 77 families and 156 genera. From the 77 plant families, Fabaceae stood first by contributing 17 (9.82\%) species followed by Lamiaceae and Solanaceae that contain $9(5.2 \%)$ species. Similarly, various studies in Ethiopia [2, 11, 37, 38] showed that Fabaceae was the dominant family among the others, whereas other studies $[19,39-44]$ noted that Asteraceae was the dominant one among others.

The result indicates that medicinal plants are unevenly distributed in the four study sites. More of the medicinal plants were found in Tsaedat-Hamlo and Hagereselam due to certain reasons. Tsaedat-Hamlo is a remote part of Ganta Afeshum District about $100 \mathrm{~km}$ from Adigrat. This has caused insufficient coverage of modern medicine, unaffordable as well as inadequate health facilities, and medical personnel. Instead, many people there use the accessible, inexpensive, and locally available traditional medicinal plants. The kebeles Hagerselam and Tsaedat-Hamlo also had a better vegetation cover and more traditional healers than Sasun-Bethaweryat and Dbla-Siet. Also, the far remote kebeles were less influenced by modernization and urbanization. Generally, urbanization and modernization negatively affect the knowledge of traditional medicinal plants. There is also a public health concern as modernization alters the practice of traditional medicine. The loss of traditional medicinal plant knowledge of these kebeles' people alters health care-seeking behavior. The residents of Sasun-Bethaweryat and Dbla-Siet were more educated and engaged in commercial activities; as a result, they

Table 11 Traditional medicinal plant knowledge of married and single informants

\begin{tabular}{llllllll}
\hline Parameter & Group of informants & $N$ & Mean & Std. deviation & $t$ value & df & $p$ value \\
\hline Marital status & Married & 58 & 12.64 & 7.357 & 2.738 & 76 & 0.008 \\
& Single & 20 & 7.65 & 5.923 & 3.043 & 40.75 & 0.004 \\
\hline
\end{tabular}


Table 12 Traditional medicinal plant knowledge of key and general informants

\begin{tabular}{llllllll}
\hline Parameter & Category of informants & $N$ & Mean & Std. deviation & $t$ value & $d f$ & $p$ value \\
\hline Way of selection & General informants & 58 & 9.6724 & 5.52947 & 5.827 & 76 & .000 \\
& Key informants & 20 & 19.4000 & 8.60477 & 4.730 & 24.630 & .000
\end{tabular}

were seeking modern medication. Less educated people tend to be less acculturated and know more medicinal plants while educated people tend to be more acculturated, know few medicinal plants, and seek Western medical treatment [45].

From the total of 173 medicinal plant species, 116 (67.44\%) plants were gathered from the natural vegetation followed by 34 (19.65\%) from home gardens. This indicates that the communities of the study area highly depend on the wild source to obtain the medicinal plants; in other words, the habit of cultivating medicinal plants in home gardens was not much developed. Similar studies conducted elsewhere in different parts of Ethiopia [10, 45-49] also reported that most of the medicinal plants were collected from natural vegetation.

The medicinal plants in the study area had diverse growth form: herbs 69 (39.88\%), shrubs 58 (33.52\%), trees 37 (21.39), and climbers 5 (2.89). The dominance of herbs and shrubs is in agreement with several studies conducted in Ethiopia [45, 48, 50-52]. In contrast, Lulekal et al. [2] reported from Mana Angetu District, southeastern Ethiopia, that shrubs there made up the highest proportion of the medicinal plants; the finding of Regassa [38] in Hawassa city, southern Ethiopia, showed that the majority of the collected medicinal plants there were trees, followed by shrubs, herbs, and climbers.

The results showed that the local people of the Ganta Afeshum District use different parts of medicinal plants

Table 13 Informant consensus factor for categorized diseases

\begin{tabular}{lllll}
\hline No. & Diseases category & Nur & $\mathrm{Nt}$ & ICF \\
\hline 1 & $\begin{array}{l}\text { Skin problems such as wound, skin rash, } \\
\text { cutaneous leishmaniasis, ringworm, } \\
\text { irritation, and skin rash }\end{array}$ & 73 & 40 & 0.458 \\
2 & $\begin{array}{l}\text { Gastrointestinal problems such as } \\
\text { abdominal pain, diarrhea, tapeworm, } \\
\text { amoeba, and gastritis }\end{array}$ & 94 & 34 & 0.645 \\
3 & $\begin{array}{l}\text { Evil eye, evil spirit, sray/dgam } \\
4\end{array}$ & 43 & 28 & 0.357 \\
5 & $\begin{array}{l}\text { Febrile illness, tonsillitis } \\
6\end{array}$ & 168 & 25 & 0.866 \\
7 & $\begin{array}{l}\text { Mar infection, eye diseases } \\
\text { scorpion bite }\end{array}$ & 19 & 14 & 0.277 \\
8 & $\begin{array}{l}\text { Men impotence, abortion, fear and } \\
\text { dislike of sex in women }\end{array}$ & 21 & 8 & 0.363 \\
9 & Headache, toothache, dandruff & 38 & 22 & 0.432 \\
\hline
\end{tabular}

to prepare remedies. Leaves were the most widely used part, which is an important finding because harvesting leaves does not have detrimental effects on the survival of the medicinal plants, whereas harvesting roots and whole plants has a negative impact on the survival. In the same way, several studies $[45,47,53-56]$ have revealed that the leaves of the medicinal plants were repeatedly used for the treatment of human and livestock ailments. On the other hand, Mesfin et al. [48] and Assefa and Abebe [57] reported that the roots were a widely utilized medicinal plant part to treat different ailments.

Most of the medicinal plants (212,64\%) were prepared to be used in the fresh form, and this indicates that fresh medicinal plants are much easier and quicker to prepare for remedy than the other forms. Abebe [11], Gebeyehu [42], and Chekole [45] reported similar results.

In Ganta Afeshum District, the common method of traditional medicine preparation is direct and immediate/unprocessed use of the medicinal plants followed by

Table $\mathbf{1 4}$ The relative healing potential of 15 most cited medicinal plants used against human ailments

\begin{tabular}{|c|c|c|c|c|c|}
\hline No. & $\begin{array}{l}\text { Scientific name } \\
\text { of the plant }\end{array}$ & $\begin{array}{l}\text { Examples of } \\
\text { ailment treated }\end{array}$ & Ip & lu & FL\% \\
\hline 1 & Withania somnifera & Febrile illness & 12 & 12 & 100 \\
\hline 2 & Lagenaria siceraria & Wound & 2 & 2 & 100 \\
\hline 3 & Nigella sativa & Abdominal pain & 1 & 1 & 100 \\
\hline 4 & Laggera tomentosa & Bleeding & 5 & 5 & 100 \\
\hline 5 & Silybum marianum & Impotence in men & 1 & 1 & 100 \\
\hline 6 & Plectranthus lanuginosus & Tonsillitis & 1 & 1 & 100 \\
\hline 7 & Linum usitatissimum & Constipation & 3 & 3 & 100 \\
\hline 8 & $\begin{array}{l}\text { Chenopodium } \\
\text { ambrosioides }\end{array}$ & Snake bite & 1 & 1 & 100 \\
\hline 9 & Vernonia amygdalina & Fungal infection & 7 & 7 & 100 \\
\hline 10 & Asparagus africanus & Evil eye & 2 & 2 & 100 \\
\hline 11 & Citrus limon & Skin problem & 23 & 24 & 95.83 \\
\hline 12 & Ruta chalepensis & Cough & 19 & 20 & 95 \\
\hline 13 & Acokanthera schimperi & Hemorrhoids & 11 & 12 & 91.66 \\
\hline 14 & Euclea racemosa & Toothache & 7 & 8 & 87.5 \\
\hline 15 & Aloe megalacantha & malaria & 9 & 11 & 81 \\
\hline
\end{tabular}


Table 15 Preference ranking of medicinal plants used for the treatment of febrile illness

\begin{tabular}{|c|c|c|c|c|c|c|c|c|c|c|c|c|}
\hline \multirow{2}{*}{$\begin{array}{l}\text { Scientific name of } \\
\text { medicinal plant }\end{array}$} & \multicolumn{10}{|c|}{ Informants (1-10) } & \multirow[t]{2}{*}{ Total } & \multirow[t]{2}{*}{ Rank } \\
\hline & 1 & 2 & 3 & 4 & 5 & & & & & 10 & & \\
\hline ordia africana & 5 & 5 & 4 & 5 & 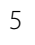 & & . & J & 3 & 5 & 48 & $1 \mathrm{st}$ \\
\hline Laggera tomentosa & 3 & 4 & 1 & 3 & 2 & 4 & , & 2 & 1 & 4 & 27 & 4th \\
\hline Medicago polymorpha & 5 & 1 & 3 & 4 & 5 & 4 & 3 & 3 & 4 & 1 & 33 & $3 r d$ \\
\hline Schinus molle & 2 & 1 & 3 & 1 & 3 & 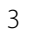 & 2 & 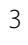 & 2 & 1 & 21 & 5th \\
\hline Vernonia amygdalina & 4 & 5 & 3 & 4 & 3 & 5 & 4 & 2 & 3 & 4 & 37 & 2nd \\
\hline
\end{tabular}

grinding and boiling in water. Elsewhere in Ethiopia, similar findings were reported [11, 37, 39, 47, 57, 58], and grinding, pounding, smoking, squeezing, burning, roasting, and powdering are common the methods of preparations of traditional medicines.

Oral administration was the most common way for traditional medicine followed by dermal, nasal, and anal. This discovery is in line with many findings of researchers [2, 16, 19, 39, 43, 58, 59] who reported that the major way of administration was oral. In contrast, Teklay et al. [20] reported that dermal was a common way of administration. Many of the prepared traditional medicines were taken by drinking followed by smearing, eating, fumigation, and chewing. This finding is concurrent with the discoveries of Gebeyehu [42] who reported that prepared remedies were applied by drinking, dropping, creaming (ointment), eating, inhaling/sniffing, and sucking. Similarly, Tamene [53] revealed that the medicinal plants prepared by traditional healers were applied by different methods such as drinking, painting, chewing, swallowing, put on, smelling, and smoking. In

Table 16 Use diversity of medicinal plants in the study area

\begin{tabular}{lll}
\hline Uses & No. of species & Percentage \\
\hline Only medicinal role & 50 & 28.90 \\
Medicinal plus other uses & 123 & 71.09 \\
Edible & 20 & 11.56 \\
Forage & 10 & 5.78 \\
Washing "soap/detergent" & 5 & 2.89 \\
Tooth brush & 15 & 8.67 \\
Spices & 7 & 4.04 \\
House construction & 13 & 7.51 \\
Fence & 14 & 8.09 \\
Stick & 6 & 3.46 \\
Fuelwood & 9 & 5.20 \\
Shade & 11 & 6.35 \\
Local alcoholic preparation & 8 & 4.62 \\
Glue & 5 & 2.89 \\
\hline
\end{tabular}

Table 17 Use value of the most important medicinal plant species in the study area

\begin{tabular}{llll}
\hline Scientific name of medicinal plant & IUi & $n$ & UV \\
\hline Rhamnus prinoides & 18 & 4 & 4.5 \\
Cordia africana & 60 & 15 & 4.00 \\
Ruta chalepensis & 15 & 4 & 3.75 \\
Allium sativum & 11 & 3 & 3.66 \\
Schinus molle & 25 & 7 & 3.57 \\
Vernonia amygdalina & 31 & 9 & 3.44 \\
Lepidium sativum & 85 & 25 & 3.40 \\
Withania somnifera & 40 & 12 & 3.33 \\
Olea europaea & 13 & 4 & 3.25 \\
Acacia albida & 6 & 2 & 3.00 \\
\hline
\end{tabular}

addition, traditional medicines of the study area were prepared with solvents and ingredients, such as water, honey, butter, cereal oils like sesame oil, teji/tella (local beer), milk/ergo (yoghurt), and tea/coffee. A similar study was carried out in Chifra District, Afar Region, Northeastern Ethiopia, by Seifu [50] who reported the Afar people and their traditional healers used solvents and additives like water, honey, sugar, and milk of goat and camels during the preparation of traditional medicines.

In Ganta Afeshum District, 74 human, 23 livestock, and15 both human and livestock ailments were recognized. This indicated that the people of the district were suffering from many ailments as compared to other areas such as in Gimbi District, western Wellega, where Tolasa [58] identified 49 human and 19 livestock ailments. In Minjar-Shenkora District, North Shewa Zone of Amhara Region, Alemayehu [43] reported 45 human ailments; in Seru District, Arsi Zone of Oromia Region, Gebrehiwot [39] reported 53 human and 17 livestock ailments; and in Wondo Genet natural forest and adjacent kebeles, Sidama Zone, SNNP Region, Tamene [53] recognized 40 human and 17 livestock ailments. Because of this burden of health problem, the people of Ganta Afeshum District widely used many medicinal plants, and that is why such a large number of medicinal plants were identified. Moreover, a single human ailment was found to be treated by several medicinal plants. This is in agreement with the findings of different scholars [40, 41, 43] who have reported wounds, headache, febrile illness, evil eye, tonsillitis, evil spirit, hemorrhoids, toothache, earache, and cough to be treated by several medicinal plants.

Men and women informants had equal traditional medicinal plant knowledge in the study area. This result is in line with the findings of Asnake et al. [55] but disagrees with the discoveries of Teklehaymanot and Giday 


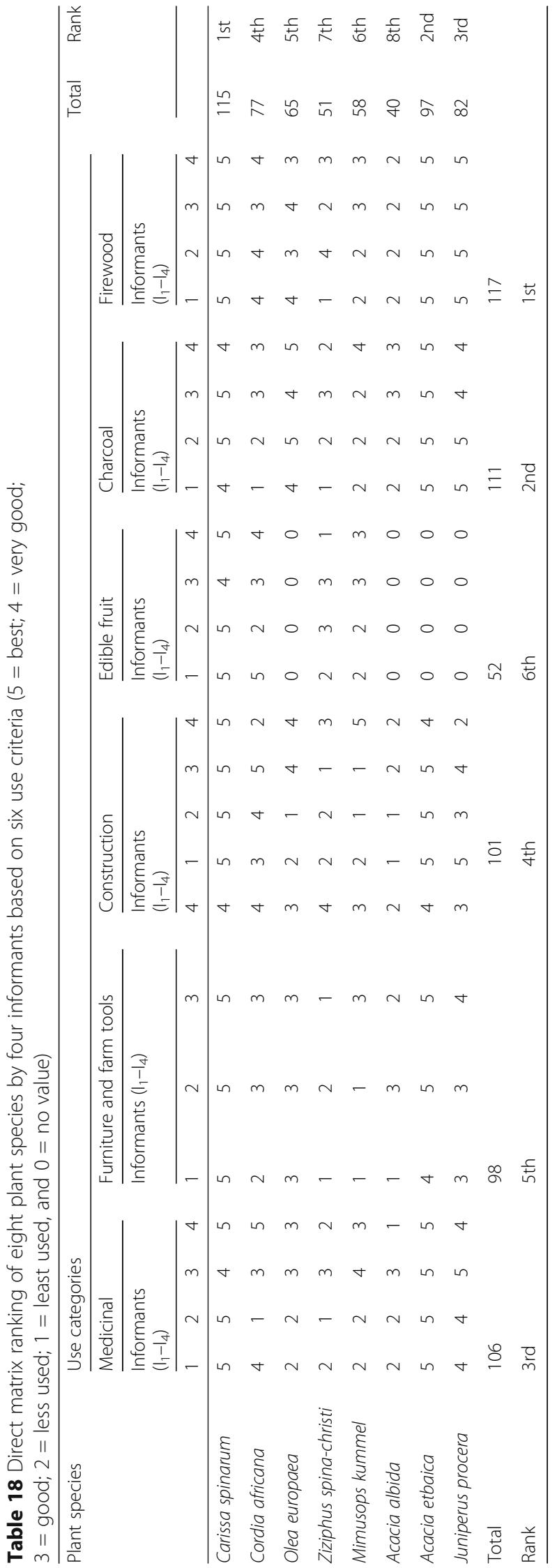


Table 19 Paired comparison of five medicinal plants for treating tonsillitis

\begin{tabular}{|c|c|c|c|c|c|c|c|c|c|c|c|c|}
\hline \multirow{2}{*}{$\begin{array}{l}\text { Scientific name of } \\
\text { medicinal plants }\end{array}$} & \multicolumn{10}{|c|}{ Informants $\left(\left.\right|_{1}-I_{10}\right)$} & \multirow[t]{2}{*}{ Total } & \multirow[t]{2}{*}{ Rank } \\
\hline & $I_{1}$ & $\mathrm{I}_{2}$ & $l_{3}$ & $\mathrm{I}_{4}$ & $I_{5}$ & $I_{6}$ & & $l_{8}$ & $l_{9}$ & $l_{10}$ & & \\
\hline лиा & 0 & 3 & 2 & 4 & 3 & 4 & 2 & 3 & 1 & 4 & 26 & 4th \\
\hline Buddleja polystachya & 1 & 2 & 3 & 4 & 3 & 0 & 2 & 3 & 4 & 4 & 30 & $3 r d$ \\
\hline Achyranthes aspera & 3 & 4 & 3 & 3 & 4 & 3 & 4 & 3 & 3 & 4 & 34 & 2nd \\
\hline Lycopersicon esculentum & 1 & 3 & 0 & 2 & 1 & 3 & 3 & 4 & 1 & 2 & 21 & 5th \\
\hline Rhamnus prinoides & 4 & 4 & 4 & 3 & 4 & 3 & 4 & 4 & 4 & 4 & 38 & 1 st \\
\hline
\end{tabular}

[59] who showed the presence of a significant difference in traditional medicinal plant knowledge between men and women. On the other hand, married informants reported significantly more medicinal plants than single informants. This is because most of the married informants were adults and more experienced with plant contact. They also possess children and livestock, they lead a family, and they are responsible for the family health care and are also the major players in using medicinal plants. Similarly, Beyene [33] reported that married informants had a better knowledge of traditional medicinal plants than single informants.

Key informants cited significantly more medicinal plants than the general informants. This is because the key informants were traditional herbalists with broad, empirical traditional medicinal plant knowledge. They cultivate, collect, process, prepare, administer, and treat patients by using medicinal plants. General informants cited fewer medicinal plants; even though they perform self-medication (homemade remedies), they are not knowledgeable about medicinal plants. Beyene [33] got similar results.

There was a significant negative correlation between the informants' educational level and their knowledge of traditional medicinal plants. This means that with a higher level of education, the knowledge of traditional medicinal plants decreases. Thus, modern education weakens the traditional medicinal knowledge of the young generation. This discovery agrees with the research carried out in Dire Dawa city, eastern Ethiopia, by Kebede et al. [47].
The more aged informants were, the more they were knowledgeable about traditional medicinal plants. Similar results were reported by Kebede et al. [47], Kefalew et al. [60], and Birhanu [61]. In the exercise of preference ranking, Cordia africana scored first rank, and Vernonia amygdalina, Medicago polymorpha, Laggera tomentosa, and Schinus molle scored second to the fifth rank, respectively, for the efficient treatment of febrile illness. In a study from Ofla wereda, the southern zone of Tigray Region [19], Cynoglossum lanceolatum was ranked first. Similarly, a study conducted by Chekole [45] in Gubalafto District showed that Cynoglossum coeruleum and Ocimum latifolium were preferred by the community to treat febrile illness. On the other hand, Momordica foetida was ranked first as the most effective for the treatment of rabies among Guji agro-pastoralists, Bule Hora District of Borana Zone, Oromia Region [54], and Nicotiana tabacum was ranked first for the treatment of snake bite in Gimbi woreda, western Wellega [58].

Furthermore, in direct matrix ranking, Carissa spinarum, Acacia etbaica, and Juniperus procera were ranked first, second, and third, respectively, showing multipurpose roles and the most preferred and extensively exploited by the local community. For this reason, they were the most threatened plant species in the study area and need conservation priority for their sustainability. Conversely, Cordia africana, Olea europaea, Mimusops kummel, Ziziphus spina-christi, and Acacia albida were the least preferred multipurpose medicinal plants and less threatened since they are not widely exploited by local communities. Similar studies were carried out elsewhere in other parts of Ethiopia like in Goma Wereda, Jima Zone of Oromia Region, Ethiopia, by Etana [40]. He used the method of direct matrix ranking and revealed that Cordia africana was the most preferred and first ranked multipurpose plant species. In another study in Seru wereda, Arsi Zone, Oromia Region, Ethiopia, Gebrehiwot [39] indicated that Acacia abyssinica was the most preferred multipurpose plant. A related study by Teklay et al. [20] indicated Cordia africana, Eucalyptus globules, Opuntia ficus-indica, and

Table 20 Jaccard's coefficient of similarity (JCS)

\begin{tabular}{|c|c|c|c|c|c|}
\hline Study area and references & $a$ & $b$ & c & JCS & Percentage \\
\hline Ganta Afeshum District (the study area) & 173 & - & - & & \\
\hline Ofla District, Ethiopia [19] & 120 & 60 & 53 & 0.22 & 22 \\
\hline Kilte Awulaelo District, Ethiopia [20] & 116 & 57 & 57 & 0.278 & 28 \\
\hline Tahitay Adiyabo and Kafta Humera districts, Ethiopia [46] & 131 & 73 & 42 & 0.171 & 17 \\
\hline Asgede Tsimbila District, Ethiopia [18] & 126 & 21 & 47 & 0.24 & 24 \\
\hline
\end{tabular}

$a$ number of species found only in Ganta Afeshum District, $b$ number of species found only in other district, $c$ number of species found in both Ganta Afeshum District and other district 


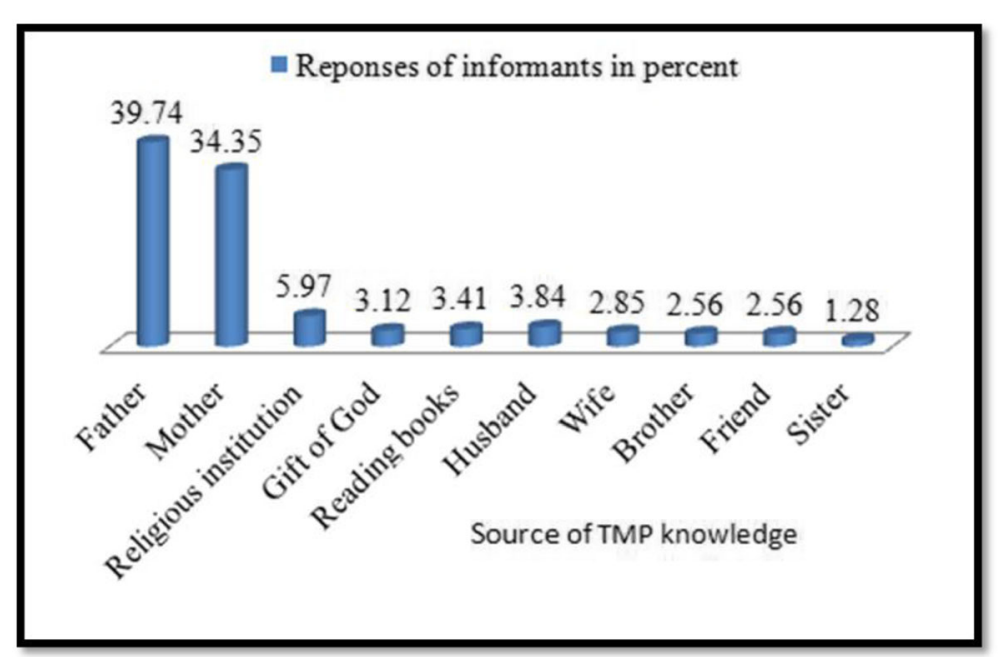

Fig. 7 Source of traditional medicinal plant knowledge in Ganta Afeshum District

Dodonia angustifolia as the most preferred multipurpose plants by the local people in Kilte Awulaelo District which is from the same zone of the study area demonstrating the presence of cultural use difference of community.

In paired comparison, Rhamnus prinoides and Achyranthes aspera were ranked first and second indicating being the most preferred and effective for treatment of tonsillitis as compared to Rumex nepalensis and Lycopersicon esculentum. Similarly, Teklay et al. [20] and Chekole [45] showed Rhamnus prinoides and Achyranthes aspera were used for the same purpose to treat tonsillitis. Moreover, ten medicinal plant species have the highest use values in the study area, indicating that they are more effective to treat ailments. Among the total documented medicinal plant species, Rhamnus prinoides followed by Cordia africana and Ruta chalepensis were used to treat the highest number of diseases. In this sense, a plant with a high use value would theoretically have a correspondingly high cultural consensus [35]. Therefore, to maintain the continuous use of plant resources in the study area, conservation priorities should be given for those multipurpose and more threatened ones.

\section{Conclusions}

Ganta Afeshum District is relatively rich in medicinal plant species. One hundred seventy-three medicinal plant species were collected and identified. These medicinal plants were used by the inhabitants to treat 112 human and livestock ailments. Wounds, febrile

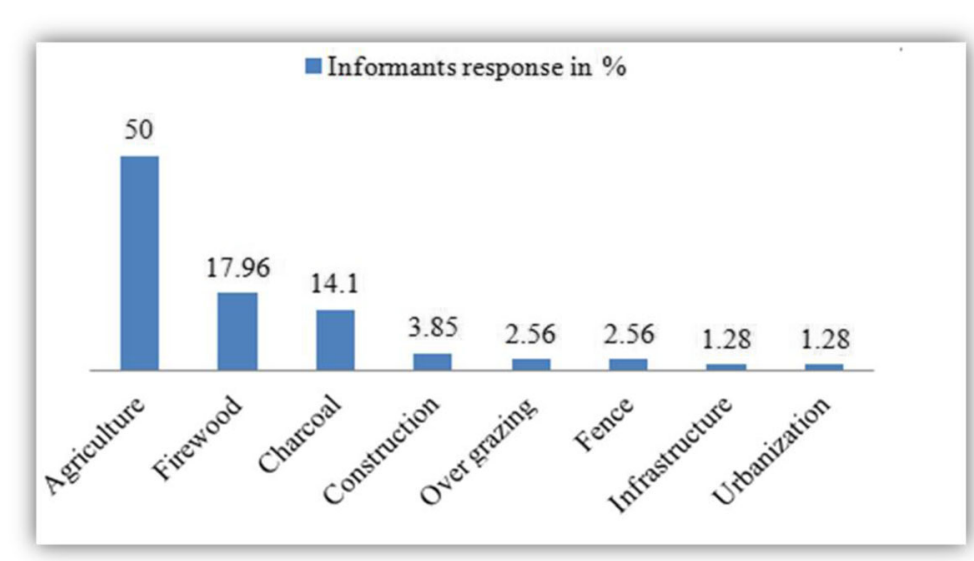

Fig. 8 Threats of medicinal plants in the study area 
Table 21 Priority ranking of threats to the knowledge of medicinal plants (values: $1=$ least threat, $5=$ highest threat)

\begin{tabular}{|c|c|c|c|c|c|c|c|c|c|c|c|c|}
\hline \multirow[t]{2}{*}{ Threats to MPs knowledge } & \multicolumn{10}{|c|}{ Informants } & \multirow[t]{2}{*}{ Total } & \multirow[t]{2}{*}{ Rank } \\
\hline & $\mathrm{I}_{1}$ & $\mathrm{I}_{2}$ & $I_{3}$ & $\mathrm{I}_{4}$ & $\mathrm{I}_{5}$ & $I_{6}$ & $\mathrm{I}_{7}$ & $I_{8}$ & $l_{9}$ & $\mathrm{I}_{10}$ & & \\
\hline The traditional healers do not show the medicinal plants & 3 & 5 & 4 & 4 & 3 & 5 & 4 & 4 & 4 & 3 & 39 & 2nd \\
\hline Expansion of schools & 3 & 4 & 3 & 4 & 3 & 4 & 3 & 4 & 3 & 3 & 34 & $3 r d$ \\
\hline The establishment of health center and posts & 3 & 3 & 3 & 3 & 3 & 3 & 3 & 3 & 2 & 3 & 29 & 4th \\
\hline Unwillingness of young generation & 5 & 4 & 5 & 5 & 4 & 4 & 4 & 5 & 4 & 5 & 45 & 1st \\
\hline Youth moving to urban areas & 3 & 2 & 2 & 3 & 3 & 2 & 2 & 3 & 2 & 3 & 25 & 5th \\
\hline
\end{tabular}

illness, abdominal pain, headache, cough, evil eye, evil spirit, men impotence, and tonsillitis were frequently occurring human ailments, whereas, leech, bloating, Newcastle, and bone fracture were common livestock ailments. This indicated that the local community depends on using medicinal plant species and the associated indigenous knowledge to prevent diverse human and livestock ailments, although modern health services are expanding.

In the study area, there was no knowledge difference between men and women informants on traditional medicinal plant knowledge, whereas, educational level and knowledge of medicinal plants of informants were negatively correlated. Thus, the age and medicinal plant knowledge of the informants were positively correlated, by which the younger informants showed less concern in sharing, recording, and examining processes of traditional medication. Greater preference ranking, use value scores, and fidelity level values of the documented medicinal plant species would enable the forthcoming phytochemical and pharmaceutical studies and conservation activities.

Natural vegetation was the main source of medicinal plants in Ganta Afeshum District followed by home gardens and farmlands. But nowadays, deforestation, agricultural expansion, overgrazing, drought, and overexploitation are threatening these plant resources and their habitat. Therefore, people of the study area should apply complementary conservation approaches (in situ and ex situ) for sustainable use of these resources and prevent species extinction.

\section{Additional files}

Additional file 1: Table S1. List of informants contacted in the study area. (DOC $134 \mathrm{~kb}$ )

Additional file 2: Table S2. List of medicinal plants recorded from the study area. (DOC $325 \mathrm{~kb}$ )

Additional File 3: Table S3. List of medicinal plants used for treating human ailments. (DOC $402 \mathrm{~kb}$ )

Additional file 4: Table S4. List of medicinal plants used for treating livestock ailments. (DOC $63 \mathrm{~kb}$ )
Additional file 5: Table S5. List of medicinal plants used for treating

human and livestock ailments. (DOC $164 \mathrm{~kb}$ )

\section{Acknowledgements}

We would like to express our heartfelt appreciation to the local informants, local administrators, and agriculture extension workers of Tabya TsaedatHamlo, Hagereselam, Dbla-Siet, and Sasun-Bethaweryat for their committed participation, factual and kind response, and sharing their traditional knowledge of medicinal plants. Besides, we would like to thank the Wereda Ganta Afeshum education office, health office, agricultural office, administration office, and plan and finance office for their support and provision of relevant information to conduct the study. We also thank the Department of Biology, College of Natural and Computational Sciences, Mekelle University, for the provision of materials and financial support. Moreover, we are indebted to Professor Ingvar Backeus, Researcher at Department of Ecology and Genetics, Plant Ecology and Evolution, Upsala University, Sweden, for his all-rounded help to develop and revise the paper critically and upgrade grammatical, linguistic, and scientific concepts of the manuscript.

\section{Funding}

The Department of Biology, College of Natural and Computational Sciences, Mekelle University, Mekelle, Ethiopia, funded the research.

\section{Availability of data and materials}

All data collected and analyzed in this paper are included within the article and attached in the form of "Appendices" as additional files. Voucher plant specimens are deposited in Mekelle University, Mekelle, Ethiopia.

\section{Authors' contributions}

GG collected and analyzed the data and was the major contributor of the study. LK devised the techniques for data collection, performed and analyzed the data, and critically reviewed and organized the paper sequence. TB revised the article and organized the references. All authors read and approved the final manuscript.

\section{Ethics approval and consent to participate}

Letters of consent were taken from Mekelle University and Ganta Afeshum woreda Administration offices, prior to the data collections. Oral consents were also obtained from the informants by performing group discussions about the objectives of the study prior to the interviews, and all data were collected through their oral consents. Besides, participants were asked about their view if their name is openly accessed, and they have clearly agreed to have their names and personal data to be published. Finally, Mekelle University certified the research finding after it was presented for the thesis defense.

\section{Consent for publication}

Not applicable.

\section{Competing interests}

The authors declare that they have no competing interests.

\section{Publisher's Note}

Springer Nature remains neutral with regard to jurisdictional claims in published maps and institutional affiliations. 


\section{Author details}

'Department of Biology, College of Natural and Computational Sciences, Mekelle University, P.O.Box 231, Mekelle, Ethiopia. ${ }^{2}$ Agazi Preparatory School, P.O.Box 014, Adigrat, Eastern Zone of Tigray, Northern Ethiopia, Ethiopia.

\section{Received: 29 March 2018 Accepted: 12 October 2018}

\section{Published online: 03 November 2018}

\section{References}

1. Wendimu T, Asfaw Z, Kelbessa E. Ethnobotanical study of medicinal plants around Dheeraa town, Arsi Zone, Ethiopia. J Ethno Pharmacol. 2007;112: 152-61.

2. Lulekal E, Kelbessa E, Bekele T, Yineger H. An ethnobotanical study of medicinal plants in Mana Angetu District, southeastern Ethiopia. J Ethnobiol Ethnomed. 2008:4(10):1746-429.

3. Innocent E. Trends and challenges toward the integration of traditional medicine in formal health care system: historical perspectives and appraisal of education curricular in sub-Sahara Africa. J Ethno Pharmacol. 2016;5(3):312-6.

4. Sofowara. Research on medicinal plants and traditional medicines in Africa. J Altern Complement Med. 2007;2(3):365-72.

5. WHO. Guidelines for registration of traditional medicines in the WHO African Region. Geneva: World Health Organization; 2010.

6. Bekel E. Study on actual situation of medicinal plants in Ethiopia. Japan Association for International Collaboration of Agriculture and Forestry; 2007.

7. Hamilton AC. Medicinal plants and conservation: issues and approaches. UK International Plants Conservation Unit, WWF-UK; 2003.

8. WHO. Promoting the role of traditional medicine in health care system. A strategy for the African region. Harare: World Health organization; 2000.

9. Kidane B, Van Ande T, Josephus L, van der Maesen G, Asfaw Z. Use and management of traditional medicinal plants by Maale and Ari ethnic communities in southern Ethiopia. J Ethnobiol Ethnomed. 2014;10:46.

10. Andarge E, Shonga A, Agize M, Tora A. Utilization and conservation of medicinal plants and their associated indigenous knowledge in Dawuro Zone: an ethnobotanical approach. Int J Med Plant Res. 2015:4(3):330-7.

11. Abebe E. Ethnobotanical study on medicinal plants used by local communities in Debark wereda, North Gonder, Amhara regional state, Ethiopia, M.Sc. Thesis. Addis Ababa: Addis Ababa University; 2011.

12. Kidane L, Nemomissa S, Woldu Z. The effects of disturbance on the population structure and regeneration potential of five dominant woody species - in Hugumburda-Gratkhassu National Forest Priority Area, Northeastern Ethiopia. Afr J Ecol. 2015;54(1):20-8.

13. Kidane L, Nemomissa S, Bekele T. Human-Forest interfaces in HugumburdaGratkhassu National Forest Priority Area, North-eastern Ethiopia. J Ethnobiol Ethnomed. 2018;14:17 https://doi.org/10.1186/s13002-018-0218-7.

14. Yirga G. Ethnobotanical study of medicinal plants in and around Alamata, southern Tigray, Northern Ethiopia. Curr Res J Biol Sci. 2010;2(5):338-44.

15. Yirga G. Assessment of traditional medicinal plants in Endrta District, Southeastern Tigray, Northern Ethiopia. Afr J Plant Sci. 2010;4:255-60.

16. Yirga G, Tefri M, Kasaye M. Survey of medicinal plants used to treat human ailments in Hawezen wereda, Northern Ethiopia. Int J Biodiversity Conserv. 2011;3(13):709-14

17. Tewelde F, Mesfin M, Tsewene S. Ethnobotanical survey of traditional medicinal practices in LaelayAdi-Yabo District, Northern Ethiopia. Int J Ophthalmol Visual Sci. 2017;2(4):80-7. https://doi.org/10.11648/j.jovs. 20170204.11.

18. Zenebe $G$, Zerihun $M$, Solomon Z. An ethnobotanical study of medicinal plants in Asgedetsimbla District northwestern Tigray region North Ethiopia. Ethnobot Res Appl. 2012;10:305-20

19. Abdurahman N. Ethnobotanical study of medicinal plants used by local people of Ofla wereda, southern Zone of Tigray region, Ethiopia, M.Sc. Thesis. Addis Ababa: Addis Ababa University; 2010.

20. Teklay A, Abera B, Giday M. An ethnobotanical study of medicinal plants in Kilte Awulaelo District, Tigray region of Ethiopia. J Ethnobiol Ethnomed. 2013:9:174-4269.

21. Asgedom A. Combating desertification in Tigray, northern Ethiopia. Sweden: the Tema Institute Campus Norrkoping; 2007.

22. Bartlett JE, Kotrlik JW, Higgins CC. Organizational research: determining appropriate sample size in survey research. Inf Technol Learn Perform J. 2001;19(1):43-50.
23. Martin GJ. Ethnobotany: a method manual. London: Chapman and Hall; 1995.

24. Edwards S, Demissew S, Hedberg I, editors. Flora of Ethiopia and Eritrea. Hydrocharitaceae to Arecaceae volume 6. Ethiopia: Department of Systematic Botany, Uppsala University, Uppsala and The National Herbarium, Addis Ababa University, Addis Ababa; 1997.

25. Edwards S, Tadesse M, Demissew S, Hedberg I, editors. Flora of Ethiopia and Eritrea. Magnoliaceae to Flacourtiaceae volume 2 part 1. Ethiopia: Department of Systematic Botany, Uppsala University, Uppsala and The National Herbarium, Addis Ababa University, Addis Ababa; 2000.

26. Edwards S, Tadesse M, Hedberg I, editors. Flora of Ethiopia and Eritrea. Canellaceae to Euphorbiaceae volume 2 part 2. Ethiopia: Department of Systematic Botany, Uppsala University, Uppsala and The National Herbarium, Addis Ababa University, Addis Ababa; 1995

27. Hedberg I, Edwards S, editors. Flora of Ethiopia and Eritrea. Poaceae (Gramineae) volume 7. Ethiopia: Department of Systematic Botany, Uppsala University, Uppsala and The National Herbarium, Addis Ababa University, Addis Ababa; 1995.

28. Hedberg I, Edwards S, editors. Flora of Ethiopia and Eritrea. Pittosporaceae to Araliaceae volume 3. Ethiopia: Department of Systematic Botany, Uppsala University, Uppsala and The National Herbarium, Addis Ababa University, Addis Ababa; 1989.

29. Hedberg I, Edwards S, Nemomissa S, editors. Flora of Ethiopia and Eritrea. Apiaceae to Dipsacaceae volume 4 part 1. Ethiopia: Department of Systematic Botany, Uppsala University, Uppsala and the National Herbarium, Addis Ababa University, Addis Ababa; 2003.

30. Hedberg I, Friis I, Edwards S, editors. Flora of Ethiopia and Eritrea. Asteraceae volume 4 part 2. Ethiopia: Department of Systematic Botany, Uppsala University, Uppsala and the National Herbarium, Addis Ababa University, Addis Ababa: 2004.

31. Hedberg I, Kelbessa E, Edwards S, Demissew S, Persson E, editors. Flora of Ethiopia and Eritrea. Plantaginaceae volume 5. Ethiopia: Department of Systematic Botany, Uppsala University, Uppsala and The National Herbarium, Addis Ababa University, Addis Ababa; 2006.

32. Heinrich M, Ankli A, Frei B, Weimann C, Sticher O. Medicinal plants in Mexico: healer's consensus and cultural importance. Soc Sci Med. 1998:47:18-63.

33. Beyene T. Ethnobotany of medicinal plants in Erob and Gulomahda districts, Eastern Zone of Tigray Region, Ethiopia. PhD Dissertation. Addis Ababa University, Addis Ababa, Ethiopia; 2015.

34. Friedman J, Yaniv Z, Dafni A, Palewitch D. A preliminary classification on the healing potential of medicinal plants, based on rational analysis of and ethnopharmacological field survey among Bedouins in the Negev Desert, Israel. J Ethnopharmacol. 1986;16:275-87.

35. Phillips O, Gentry AH, Reynel C, Wilkin P, Galvez-Durand BC. Quantitative ethnobotany and Amazonian conservation. Conserv Biol. 1994;8:225-48.

36. Kent M, Coker P. Vegetation description and analysis: a practical approach London: Belhaven Press; 1992.

37. Megersa M. Ethnobotanical Study of Medicinal Plants in Wayu Tuka Wereda East Wollega Zone of Oromia Region, Ethiopia M.Sc. Thesis. Addis Ababa University, Addis Ababa, Ethiopia; 2010.

38. Regassa R. Assessment of indigenous knowledge of medicinal plant practice and mode of service delivery in Hawassa city, southern Ethiopia. J Med Plants Res. 2013;7(9):517-35.

39. Gebrehiwot M. An ethnobotanical study of medicinal plants in Seru wereda Arsi Zone of Oromia Region, Ethiopia, M.sc. Thesis. Addis Ababa: Addis Ababa University; 2010.

40. Etana B. Ethnobotanical study of traditional medicinal plants of Goma wereda Jima Zone of Oromia Region, Ethiopia, M.Sc. Thesis. Addis Ababa: Addis Ababa University; 2010

41. Amenu E. Use and management of medicinal plants by indigenous people of ejaji area (chelya woreda) West Shoa, Ethiopia, M.Sc. Thesis. Addis Ababa: Addis Ababa University; 2007.

42. Gebeyehu G. An ethnobotanical study of traditional use of medicinal plants and their conservation status in mecha wereda, west Gojjam Zone of Amhara Region, Ethiopia, M.Sc.Thesis. Addis Ababa: Addis Ababa University; 2011

43. Alemayehu G. Ethnobotanical study on medicinal plants used by indigenous local communities in Minjar-shenkora wereda, north Shewa Zone of Amhara Region, Ethiopia, M.Sc.Thesis. Addis Ababa: Addis Ababa University; 2010. 
44. Getaneh S, Girma Z. An ethnobotanical study of medicinal plants in Debre libanos wereda central Ethiopia. Acad J. 2014:366-79.

45. Chekole G. Ethnobotanical study of medicinal plants used against human ailments in Gubalafto District, Northern Ethiopia. J Ethnobiol Ethnomed. 2017;13:55. https://doi.org/10.1186/s13002-017-0182-7.

46. Gidey M, Beyene T, Yirga G, Signorini AM, Bruschi P. Traditional medicinal plants used by Kunama ethnic group in Northern Ethiopia. J Med Plants Res. 2015;9(15):494-509.

47. Kebede A, Ayalew S, Mesfin A, Mulualem G. Ethnobotanical investigation of traditional medicinal plants commercialized in the markets of Dire Dawa city, eastern Ethiopia. J Medicinal Plants Stud. 2016:4(3):170-8.

48. Mesfin F, Demissew S, Teklehaymanot T. An ethnobotanical study of medicinal plants in Wonago Woreda, SNNPR, Ethiopia. J Ethnobio Ethnomed. 2009;5:28.

49. Hailemariam T, Demissew S, Asfaw Z. An ethnobotanical study of medicinal plants used by local people in the lowlands of Konta Special Woreda, southern nations, nationalities and people regional state, Ethiopia. J Ethnobiol Ethnomed. 2009;5:26.

50. Seifu T. Ethnobotanical and ethnopharmaceutical studies on medicinal plants of Chifra district, afar region, north eastern Ethiopia, M.Sc.Thesis. Addis Ababa: Addis Ababa University; 2004.

51. Guidy M. An ethnobotanical study of medicinal plants used by Zay people in Ethiopia. CBM: skriftserie. 2001;3:81-99.

52. Belayneh A, Asfaw Z, Demissew S, Bussa NF. Medicinal plants potential and use by pastoral and agro-pastoral communities in Erer Valley of Babile Wereda, eastern Ethiopia. J Ethnobiol Ethnomed. 2012:8:42

53. Tamene S. An ethnobotanical study of medicinal plants in Wondo Genet natural forest and adjacent kebeles Sidama zone, SNNP region, Ethiopia, M. Sc. Thesis. Addis Ababa: Addis Ababa University; 2011.

54. Ashagre M. Ethnobotanical study of medicinal plants in GuiAgro- Pastorilist, Blue Hora district of Borona zone, Oromia region, Ethiopia, M.Sc. Thesis. Addis Ababa: Addis Ababa University; 2011.

55. Asnake S, Teklehaymanot T, Hymete A, Erko B, Giday M. Survey of medicinal plants used to treat malaria by Sidama people of Boricha District Sidama zone, South Region of Ethiopia. Evid Based Complement Alternat Med. 2016;10:1155.

56. Chekole G, Asfaw Z, Kelbessa E. Ethnobotanical study of medicinal plants in the environs of Tara-Gedam and Amba remnant forests of Libo Kemkem District, Northwest Ethiopia. J Ethnobiol Ethnomed. 2015;11:4.

57. Assefa A, Abebe T. Ethnobotanical study of wild medicinal trees and shrubs in Benna Tsemay District, southern Ethiopia. J Sci Dev. 2014;2(1):17-33.

58. Tolasa E. Use and conservation of traditional medicinal plants by indigenous people in gimbi woreda, western wellega Ethiopia, M.Sc.Thesis. Addis Ababa: Addis Ababa University; 2007.

59. Teklehaymanot T, Giday M. Ethnobotanical study of medicinal plants used by people in Zegie Peninsula, northwestern Ethiopia. J Ethnobiol Med. 2007; 3(12):1746-4269.

60. Kefalew A, Asfaw Z, Kelbessa E. Ethnobotany of medicinal plants in Ada'a district, East Shewa Zone of Oromia Regional State, Ethiopia. J Ethnobiol Ethnomed. 2015:11:25.

61. Birhanu T, Abera D, Ejeta E. Ethnobotanical study of medicinal plants in selected Horro Gudurru Woredas, Western Ethiopia. J Biol Agriculture Healthcare. 2015;5(1):2224-3208.

Ready to submit your research? Choose BMC and benefit from:

- fast, convenient online submission

- thorough peer review by experienced researchers in your field

- rapid publication on acceptance

- support for research data, including large and complex data types

- gold Open Access which fosters wider collaboration and increased citations

- maximum visibility for your research: over $100 \mathrm{M}$ website views per year

At BMC, research is always in progress.

Learn more biomedcentral.com/submissions 